\title{
sciendo
}

DOI: 10.2478/fv-2019-0016

FOLIA VETERINARIA, 63, 2: 30-36, 2019

\section{ANTHELMINTIC ACTIVITY OF HYMENODICTYON PACHYANTA STEM BARK EXTRACTS AGAINST HAEMONCHUS CONTORTUS}

\author{
Olayemi, D. O. ${ }^{1}$, Onakpa, M. M. ${ }^{2}$, Jegede, O. C. ${ }^{1}$ \\ ${ }^{1}$ Department of Parasitology and Entomology \\ ${ }^{2}$ Department of Veterinary Pharmacology and Toxicology \\ Faculty of Veterinary Medicine, P.M.B. 117, University of Abuja \\ Nigeria
}

droladanielsdvm@gmail.com

\begin{abstract}
The development of host resistance to anthelmintics and the increasing cost of commercial anthelmintics have encouraged the need for the in vitro anthelmintic evaluation of crude extract and fractions of Hymenodictyon pachyanta plant as alternative drugs against Haemonchus contortus. H. contortus is one of the most prevalent and highly pathogenic parasitic nematodes in small ruminant farming globally. $H$.pachyanta stem bark is a prospective plant used by the local and indigenous farmers of Nsukka, Enugu state, Nigeria. The stem bark of $H$.pachyanta were collected, dried, pulverized and extracted with $80 \%$ methanol. The purpose of this study was to investigate the in vitro anthelmintic effects of these crude extract and fractions against $H$. contortus in sheep and goats. The two extracts (crude and fractions) of $H$. pachyanta were tested by the egg hatch assay (EHA) and the larval development inhibition assays (LDIA) and to compared the results with albendazole (as the positive control). The concentrations for the crude extract and albendazole used for this study were $0.78,1.56,3.125$,
\end{abstract}

6.25 and $12.5 \mathrm{mg} \cdot \mathrm{ml}^{-1}$. The results demonstrated that the crude extracts, fractions and albendazole all at the concentration doses of $12.5 \mathrm{mg} \cdot \mathrm{ml}^{-1}$ produced $100 \%$ inhibition of egg hatching and larval development. Statistically, there was no significant difference $(P>0.05)$ in the mean percentage inhibition of egg hatching and larval development inhibition of the crude extracts and fractions when compared with albendazole. However, a significant difference $(\mathrm{P}<\mathbf{0 . 0 5})$ was observed with $\mathrm{n}$-butanol fraction which inhibited $\mathbf{9 6 . 1 7 \%}$ of egg hatchability. All of the extracts and albendazole showed ovicidal and larvicidal effects and were able to induce over $50 \%$ of the egg hatching and mortality of larvae at the concentration ranges of $0.78-12.5 \mathrm{mg} \cdot \mathrm{ml}^{-1}$. The results obtained from our study suggest that $H$. pachyanta had ovicidal and larvicidal activity against $H$. contortus and that the bioactive plants compounds responsible for this effect could be attributed to the presence of tannins, alkaloids and the saponins contained in the crude extracts.

Key words: anthelmintic; extract; fractions; H.pachyanta; $H$. contortus; larvicidal; ovicidal; resistance 


\section{INTRODUCTION}

Sheep and goat parasitism in the past has been a continuous problem experienced by the small livestock producers. Parasitic gastro-enteritis is a clinical and sub-clinical condition resulting from one or in combinations of two or more parasitic infections of the gastrointestinal (GI) tracts. This poses a serious health challenge to the ruminant animals by limiting their productivity due to morbidity and mortality of the animals $[16,24]$. Diseases due to gastro-intestinal nematodes are major economic constraints to grazing sheep production globally [19]. Haemonchus contortus is one of the GI parasites that causes an alarming threat to the development and production of ruminant livestock. They limit the production by causing high mortality rates in herds during the rainy season [26]. Among helminths types that infect livestock, $H$. contortus ranks highest in importance globally. They are considered to be the most prevalent and devastating species, thriving mostly in warm and humid areas. The death rate due to haemonchosis is very high and may be up to $50 \%$ in some small ruminant communities [10].

The continuous and indiscriminate use of the synthetic anthelmintics has increased the resistance of parasitic helminths to anthelmintics [15]. Anthelmintic resistance is considered a major challenge in most sheep-rearing countries [17]. The current alternative and approach to reduce anthelmintic resistance is: phototherapy, use of medicinal and herbal plants (leaves, stem, barks, roots and seeds) to formulate good alternative herbal preparations with high anthelmintic effects that will complement the commercial anthelmintics $[14,25,34]$.

The Hymenodictyon pachyantha (Rubiaceae) genus comprises twenty two species of which eleven are mostly found in the Madagascar region, four in Asia and seven in Tropical Africa $[6,29]$. It is a tree found in the tropical forest of Africa, Cameroon, Nigeria (oke igbo), Niger and Benin [12]. They are medium-sized trees and grow up to 35 meters tall, with simple, opposite, decussate, subcoriaceous or coriaceous and membranaceous leaves. The West African $H$.pachyantha has the largest leaf blades, 8-31 by $5-11 \mathrm{~cm}$. A previous study revealed that the $H$.floribundum trunk bark has been used in Angola folk medicine to treat fever, while the H.excelsum bark was used to kill tapeworms. The leaves and bark of H.excelsum possess pharmacological activities: such as antimicrobial, antico- agulant, anti-inflammatory, antioxidant, analgesic, and antipyretic activities $[2,7,8,23,32]$.

This study evaluates the in vitro anthelmintic properties of the crude extracts and fractions of the H.pachyanta stem-bark extracts against $H$.contortus eggs and larval inhibition assay and validate its anthelmintic potentials.

\section{MATERIALS AND METHODS}

\section{Plant collection and extraction}

Fresh leaves of $H$. pachyanta were collected from Orba, in Udenu Local Government Area, Enugu state, Nigeria. The plants were identified by a Taxonomist, Mr. A. Ozioko of the Department of Biological Science University of Nigeria, Nsukka and a voucher specimen was deposited at the Department of Parasitology and Entomology, University of Abuja, Nigeria. The leaves were air-dried, pulverized and sieved. Three hundred grams of the pulverized plant material was extracted using $80 \%$ methanol in a Soxhlet apparatus. The crude extract was concentrated in vacuo using a rotary evaporator coupled to a thermo-regulator.

Table 1. Qualitative phytochemical analysis

\begin{tabular}{llc}
\hline Phytochemical analysis & Plant constituents & $\begin{array}{c}\text { H. pachyanta } \\
\text { extract }\end{array}$ \\
\hline Froting test & Saponin & + \\
Dragendoff test & Alkaloid & + \\
Molish test & Carbohydrate & + \\
Leiberman Bucchard test & Steroid & + \\
Leiberman Bucchard test & Triterpine & + \\
Keller kiliani test & Cardiac glycoside & + \\
Ferric chloride test & Tannin & + \\
Sodium hydroxide & Flavonoid & + \\
Bontrager's test & Anthraquinone & + \\
Ferric chloride test & Phenol & + \\
\hline
\end{tabular}

$(+)$ indicates the presence of the component, while (-) indicates the absence of the phytochemical compound in the extract. The plant extract had all the listed secondary metabolites except for steroid and cardiac glycoside. 


\section{Solvent partitioning}

The crude extract was suspended in water and partitioned subsequently using petroleum ether, ethyl acetate and n-butanol, using $150 \mathrm{ml}$ of each solvent according to their polarity. The whole process was repeated three times for each solvent [30].

\section{Collection of eggs and parasites}

The collection of the parasites was done immediately after evisceration. The abomasum of a sheep naturally infected with $H$.contortus was incised and the contents washed in a clean plastic bucket and then taken to the laboratory. Parasites were recovered by passing the abomasal contents through a sieve of $100-\mu \mathrm{m}$-diameter mesh. Adult female $H$. contortus obtained from the abomasal washings were individually picked up with a wire loop under an illuminator (Picker X-ray). The female H. contortus were identified and separated from other parasites and were crushed in a mortar, using pestle, to obtain the eggs. The eggs were further mixed with autoclaved horse faeces and were incubated at $27^{\circ} \mathrm{C}$ for 8 days after which the larvae (L1) were harvested using modified Baerman's apparatus [31].

\section{In vitro egg hatch assay}

The Egg Hatch Assay (EHA) was performed using the World Association for the Advancement of Veterinary Parasitology (WAAVP) guidelines [9]. Adult female H. contortus were obtained from the abomasum of naturally infected sheep slaughtered at the dogarawa abattoir, Zaria. The abomasa were removed soon after the evisceration and parasites were recovered by passing the abomasal contents through a sieve of $100-\mu \mathrm{m}$-diameter mesh. The parasites were individually picked out with a wire loop under an illuminator (Picker X-ray). The female H. contortus were identified and separated from other parasites [33]. The female worms were separated and suspended in distilled water and later crushed with mortar and pestle to liberate the eggs as described by Simon et al. [31].

Approximately 200 eggs contained in $0.08 \mathrm{ml}$ were pipetted into a 96-flat-bottomed micro titre plate in addition with $0.5 \mathrm{ml}$ at different concentrations $(0.78,1.56,3.125$, 6.25 and $12.5 \mathrm{mg} \cdot \mathrm{ml}^{-1}$ ) of the crude extract and the fractions. Similarly, the same process was repeated with albendazole in addition with $0.5 \mathrm{ml}$ at different concentrations $\left(0.78,1.56,3.125,6.25\right.$ and $\left.12.5 \mathrm{mg}^{-\mathrm{ml}^{-1}}\right)$ and distilled water $(0.5 \mathrm{ml})$. The eggs were incubated for 48 hours at $27^{\circ} \mathrm{C}$ and $70 \%$ relative humidity. Each concentration was done in triplicate. After 48 hours of incubation, a drop of Lugol's iodine was added to stop further hatching. Thereafter, using a pipette, the content of each well of the microtitre plate was placed on a glass slide and examined microscopically at $\times 40$ magnification. All the unhatched eggs as well as the larvae (L1) in each well were counted and recorded.

\section{Evaluation of the larvicidal activity of the extract}

The evaluations of the larvicidal activities of the different portions of the extracts and fractions were done according to the methods described by Wabo et al. [34]. Albendazole, at different concentration and distilled water, were used as treated and untreated controls, respectively. One hundred (100) larvae of $H$. contortus contained in $0.1 \mathrm{ml}$ of a suspension were added into each of a labelled 96-well flat-bottom microtitre plate. Thereafter, $0.5 \mathrm{ml}$ of the different concentrations $\left(0.78,1.56,3.125,6.25\right.$ and $\left.12.5 \mathrm{mg}^{-\mathrm{ml}^{-1}}\right)$ of the extracts and fractions were added. Each test was done in triplicate. The plates were covered with foil and left at room temperature $\left(25^{\circ} \mathrm{C}\right)$ for 24 hours. Thereafter, the content of each well was stirred and pipetted onto a clean glass slide and then examined under a microscope at $\times 4$ magnification to count the number of larvae that were dead or alive. The movements or migration of the larva from one point to the other was used to consider if the parasite was still alive or dead. The larva was considered dead if it showed no observable motion after $5-10$ seconds.

\section{Statistical analysis}

The mean $( \pm S D)$ percentages inhibition of eggs hatched and larval development at different concentrations with the controls were compared and performed by one-way ANOVA. The statistical analysis was also determined by using the SPSS version 20 to aid easy analysis. The Post Hoc statistical significance test employed was the least square difference (LSD), the difference between the means was considered significant at $\mathrm{P}<0.05$.

\section{RESULTS}

The crude extracts of $H$. pachyanta stem bark and fractions significantly $(\mathrm{P}<0.05)$ inhibited the hatching of eggs and larval development of H.contortus in a concentrationdose response. There was a positive correlation between the 
Table 2. Mean ( \pm SD) percentage inhibition of the egg hatch of $H$. contortus at different concentrations of $H$. pachyanta extract [mg. $\mathrm{ml}^{-1}$ ] and albendazole $\left[\mathrm{mg} \cdot \mathrm{ml}^{-1}\right.$ ]

\begin{tabular}{|c|c|c|c|c|c|}
\hline Treatments & $0.78 \mathrm{mg} \cdot \mathrm{ml}^{-1}$ & $1.56 \mathrm{mg} \mathrm{ml}^{-1}$ & $3.125 \mathrm{mg} \cdot \mathrm{ml}^{-1}$ & $6.25 \mathrm{mg} \cdot \mathrm{ml}^{-1}$ & $12.50 \mathrm{mg} \cdot \mathrm{ml}^{-1}$ \\
\hline H. pachyanta & $96.3 \pm 1.53^{b}$ & $97.67 \pm 1.04^{b}$ & $98.67 \pm 0.58^{b}$ & $99.6 \pm 0.289^{b}$ & $100 \pm 0.00^{b}$ \\
\hline Albendazole & $96.8 \pm 1.04^{b}$ & $98 \pm 0.50^{b}$ & $99 \pm 0.00^{b}$ & $99.8 \pm 0.289^{b}$ & $100 \pm 0.00^{b}$ \\
\hline DW & $6.2 \pm 2.33$ & & & & \\
\hline
\end{tabular}

DW-distilled water; means with different superscript letters $\left({ }^{a, b}, c\right)$ differed significantly $(P<0.05)$ from the positive control group

Table 3. Mean $( \pm$ SD) percentage inhibition of larval development of $H$. contortusat different concentrations of H. pachyanta extract [mg. $\mathrm{ml}^{-1}$ ] and albendazole $\left[\mathrm{mg} \cdot \mathrm{ml}^{-1}\right]$

\begin{tabular}{|c|c|c|c|c|c|}
\hline Treatments & $0.78 \mathrm{mg} \cdot \mathrm{ml}^{-1}$ & $1.56 \mathrm{mg} \cdot \mathrm{ml}^{-1}$ & $3.125 \mathrm{mg} \cdot \mathrm{ml}^{-1}$ & $6.25 \mathrm{mg} \cdot \mathrm{ml}^{-1}$ & $12.50 \mathrm{mg} \cdot \mathrm{ml}^{-1}$ \\
\hline H. pachyanta & $70.6 \pm 4.70^{b}$ & $75.67 \pm 3.50^{b}$ & $82.3 \pm 5.85^{\mathrm{a}}$ & $92 \pm 3.00^{\mathrm{a}}$ & $100 \pm 0.00^{b}$ \\
\hline Albendazole & $73.47 \pm 2.25^{b}$ & $77 \pm 1.73^{b}$ & $91.3 \pm 3.20^{b}$ & $100 \pm 0.00^{b}$ & $100 \pm 0.00^{b}$ \\
\hline DW & $13 \pm 1.45$ & & & & \\
\hline
\end{tabular}

DW-distilled water; means with different superscript letters $\left({ }^{a, b}, c\right)$ differed significantly $(P<0.05)$ from the positive control group

Table 4. Mean ( \pm SD) percentage inhibition of the egg hatch of $H$. contortusat different concentrations of $H$. pachyanta fraction $\left[\mathrm{mg} \cdot \mathrm{ml}^{-1}\right.$ ] and albendazole $\left[\mathrm{mg} \cdot \mathrm{ml}^{-1}\right.$ ]

\begin{tabular}{|c|c|c|c|c|c|}
\hline Fractions & $0.78 \mathrm{mg} \cdot \mathrm{ml}^{-1}$ & $1.56 \mathrm{mg} \cdot \mathrm{ml}^{-1}$ & $3.125 \mathrm{mg} \cdot \mathrm{ml}^{-1}$ & $6.25 \mathrm{mg} \cdot \mathrm{ml}^{-1}$ & $12.50 \mathrm{mg} \cdot \mathrm{ml}^{-1}$ \\
\hline n-butanol & $87.7 \pm 6.89^{a}$ & $90.17 \pm 5.96^{\mathrm{a}}$ & $92.5 \pm 4.48^{a}$ & $94.3 \pm 4.48^{\mathrm{a}}$ & $96.17 \pm 3.55^{\mathrm{a}}$ \\
\hline Ethylacetate & $90 \pm 6.50^{c}$ & $92.17 \pm 5.90^{c}$ & $94.5 \pm 4.82^{c}$ & $96.77 \pm 3.3^{c}$ & $100 \pm 0.00^{b}$ \\
\hline Petroleum ether & $93.07 \pm 2.72^{d}$ & $95.03 \pm 2.25^{d}$ & $96.7 \pm 2.60^{d}$ & $98.3 \pm 2.47^{e}$ & $100 \pm 0.00^{b}$ \\
\hline Aqueous & $89.17 \pm 1.44^{\mathrm{e}}$ & $92.5 \pm 1.81^{e}$ & $93.6 \pm 1.65^{e}$ & $95.83 \pm 1.89^{b}$ & $99.5 \pm 0.87^{b}$ \\
\hline Albendazole & $96.83 \pm 1.04^{b}$ & $98 \pm 0.50^{b}$ & $99 \pm 0.00^{b}$ & $99.83 \pm 0.28^{b}$ & $100 \pm 0.00^{b}$ \\
\hline DW & $6.2 \pm 2.33$ & & & & \\
\hline
\end{tabular}

DW-distilled water; means with different superscript letters $(a, b, c, d, e)$ differed significantly $(P<0.05)$ from the positive control group

Table 5. Mean ( \pm SD) percentage inhibition of larval development of $H$. contortusat different concentrations of $H$. pachyanta fraction $\left[\mathrm{mg} \cdot \mathrm{ml}^{-1}\right.$ ] and albendazole $\left[\mathrm{mg} \cdot \mathrm{ml}^{-1}\right]$

\begin{tabular}{|c|c|c|c|c|c|}
\hline Fractions & $0.78 \mathrm{mg} \cdot \mathrm{ml}^{-1}$ & $1.56 \mathrm{mg} \mathrm{ml}^{-1}$ & $3.125 \mathrm{mg} \cdot \mathrm{ml}^{-1}$ & $6.25 \mathrm{mg} \cdot \mathrm{ml}^{-1}$ & $12.50 \mathrm{mg} \mathrm{ml}^{-1}$ \\
\hline n-butanol & $55.6 \pm 3.00$ & $60.5 \pm 2.00^{\mathrm{a}}$ & $60.5 \pm 2.00^{\mathrm{a}}$ & $80 \pm 2.00^{\mathrm{a}}$ & $99 \pm 1.32^{b}$ \\
\hline Ethylacetate & $62 \pm 2.00^{c}$ & $72.0 \pm 4.00^{c}$ & $75.3 \pm 5.03^{c}$ & $90.17 \pm 1.61^{c}$ & $99 \pm 1.00^{b}$ \\
\hline Petroleum ether & $60 \pm 2.00^{d}$ & $67.3 \pm 1.85^{d}$ & $78.17 \pm 2.05^{d}$ & $92 \pm 2.00^{d}$ & $100 \pm 0.00^{b}$ \\
\hline Aqueous & $65 \pm 5.00^{e}$ & $74.3 \pm 2.00^{b}$ & $82.0 \pm 4.0^{e}$ & $90.0 \pm 4.00^{e}$ & $100 \pm 0.00^{b}$ \\
\hline Albendazole & $73.47 \pm 2.25^{b}$ & $77 \pm 1.73^{b}$ & $91.3 \pm 3.2^{b}$ & $100 \pm 0.00^{b}$ & $100 \pm 0.00^{b}$ \\
\hline DW & $13 \pm 1.45$ & & & & \\
\hline
\end{tabular}

DW-distilled water; means with different superscript letters $(a, b, c, d, e)$ differed significantly $(P<0.05)$ from the positive control group 
concentrations of the crude extract, fraction, albendazole and the rates of egg hatch inhibition such that, as the drug concentration increased, the egg hatch and larval development inhibition rate increased (Tables 2, 3, 4 and 5). Although there were variations in the concentrations ( $\mathrm{mg} \cdot \mathrm{ml}^{-1}$ ) required for each of the crude extracts and fractions to show individual anthelmintic activity and efficacy. At the concentration of $12.5 \mathrm{mg}^{-\mathrm{ml}^{-1}}$ the crude extracts and albendazole inhibited $100 \%$ of the hatching of eggs and larval development of the H.contortus showing no significant difference $(\mathrm{P}>0.05)$ in their anthelmintic activity, while a significant difference $(\mathrm{P}<0.05)$ was observed with $96.17 \%$ inhibition of egg hatching by n-butanol when compared with albendazole.

\section{DISCUSSION}

All of the extracts of $H$. pachyanta showed significant inhibitory effects on the egg hatching of $H$. contortus. Even though there were differences in activity between the extracts of the plant, they were statistically insignificant $(\mathrm{P}>0.05)$. However, a significant difference $(\mathrm{P}<0.05)$ existed between n-butanol and albendazole which inhibited the hatching of eggs at $96.17 \%$. The inhibitory effect of the crude extract and fractions on the egg hatching of $H$. contortus eggs were not significantly different $(\mathrm{P}>0.05)$ from the effects produced by albendazole (standard drug). Previous studies revealed that plant extracts usually produce graded dose response when tested on helminth eggs [2, 3,27]. This study also showed an increase in the mean larval mortality rates with an increase in concentration of all the extracts tested. The extracts caused significant $(\mathrm{P}<0.05)$ larva mortality rates from concentration ranges of $0.78-12.5 \mathrm{mg}$. $\mathrm{ml}^{-1}$. The larvicidal activity of the crude and fractions of $H$. pachyanta on $H$. contortus larvae were not significantly different $(\mathrm{P}>0.05)$ from the effects produced by albendazole. The larvicidal inhibitory effects observed in this study was due to the penetration of the active chemical constituents of the extracts across the cuticle of the larvae into their circulatory system when the larvae were brought in contact with the extracts [27].

This study confirms the anthelmintic effects of H.pachyanta against $H$. contortus. At the concentration of $12.5 \mathrm{mg} \cdot \mathrm{ml}^{-1}$, all of the crude extracts and albendazole produced $100 \%$ inhibition of the egg hatch and larval development on H.con- tortus except for n-butanol fraction which had $96.17 \%$. However, there was no significant difference $(\mathrm{P}>0.05)$ between the extracts and albendazole. An increase in the concentrations of the crude extract and fractions increased the percentage of inhibition of the anthelmintic activities of the extracts on the parasites in a dose-dependent manner (Tables 2, 3, 4 and 5). Our study compared with the previous studies done by Wabo et al. [34] and Gatachew et al. [13]. Our study also agreed with $\mathrm{P}$ a s so et al. [28] who demonstrated that the extracts of the essential oil of ocimum gratissimum inhibited $96.94 \%$ of the egg hatching of H.contortus at the lowest concentration of $2.5 \mathrm{mg} \cdot \mathrm{ml}^{-1}$, which was compared with $0.78 \mathrm{mg} \cdot \mathrm{ml}^{-1}$ of the crude extract that inhibited $96.3 \%$ of the egg hatching of H. contortus in our study. With the ovicidal and larvicidal effects of H.pachyanta on H.contortus eggs and larvae, our study agreed with Maitreya [20], who reported the use of H. excelsum bark to kill tapeworms.

In our study, the anthelmintic effects of $H$.pachyanta could be attributed to one or more of the phytochemicals present in the stem bark such as tannins, triterpenes, saponin, polyphenols anthraquinones and contained toxic alkaloids (hymenodictyonim and hymenodictine) a bitter substance, which could also may be responsible for the activity observed in our study $[7,11,18]$. The tannins and saponins contained in medicinal plants have been reported to possess anthelmintics compounds [1, 4, 22, 31]. The effect of tannins is similar to some synthetic phenolic anthelmintics like niclosamide and nitroxynil, which interferes with the generation of energy by uncoupling oxidative phosphorylation in the helminth parasites [21]. Tannins also have the ability to bind free protein available for larval nutrition and reduce the nutrients available for the parasites chemical metabolism or directly through inhibition of oxidative phosphorylation which results in larval starvation and finally larval death [5].

\section{CONCLUSIONS}

Our study established the anthelmintic effects of $H$. $p a$ chyanta crude extract and fractions which offers a potential inhibitory ovicidal and larvicidal effects against the eggs hatching and larval development of H.contortus. Therefore, in vivo studies are required to investigate the safety, toxicity profile and to authenticate the therapeutic poten- 
tials of $H$.pachyanta extracts for use as an anthelmintic compound in the treatment $H$. contortus parasites. Further isolation and screening of the plant bioactive compounds of $H$.pachyanta responsible for this ovicidal and larvicidal activity are needed.

\section{ACKNOWLEDGEMENTS}

The authors are grateful to Yusuf Magaji of the Department of Parasitology and Entomology, Faculty of Veterinary Medicine, ABU, Zaria, Kabiru Ibrahim and Adamu Mohammed, both of the Department of Pharmacognosy and Drug Development, Faculty of Pharmaceutical Sciences, ABU, Zaria.

\section{REFERENCES}

1. Ademola, I. O., Akanbi, A.I., Idowu, S.O., 2005: Comparative nematocidal activity of chromatographic fractions of Leucaena leucocephala seed against gastrointestinal sheep nematodes. Pharma. Biol., 43, 7,599-604.DOI: 10.1080 /13880200500301761.

2. Ademola, I.O., Eloff, J.N., 2011: Anthelmintic efficacy of cashew (Anarcadium occidentale L.) on in vitro susceptibility of the ova and larvae of Haemonchus contortus. Afr. J. Biotech., 10, 7, 9700-9705. DOI: 10.1017/S1466252316000049.

3. Alawa, C.B.I., Adamu, A.M., Gefu, J.O., Ajanusi, O. J., Abdu, P. A., Chiezey, N.P., et al., 2003: In vitro screening of two Nigerian medicinal plants (Vernonia amygdalina and Annona senegalensis) for anthelmintic activity. Vet. Parasitol. 113, 1, 73-81. DOI: 10.1080/13880200701498978.

4. Alonso-Diaz, M.A., Torres-Acosta, J.F. J., Sandoval-Castro, C. A., Hoste, H., 2011: Comparing the sensitivity of two in vitro assay to evaluate the anthelmintic activity of tropical tannins rich plant extracts against Haemonchus contortus. Vet. Parasitol., 181, 2-4, 360-364. DOI: 10.1016/j.vetpar. 2011. 03.052.

5. Athanasiadou, S., Githiori, J., Kyriazakis, I., 2007: Medicinal plants for helminth parasite control: facts and fiction. Animal, 1, 9, 1392-400. DOI:10.1017/S1751731107000730.

6. Borges, C. M. P., Diakanawma, C., de Mendonça, D. I. M. D., 2010: Iridoids from Hymenodictyon floribundum. J. Braz. Chem. Soc., 21, 6, 1121-1125. DOI: 10.1590/S0103-5053201 0000600023 .
7. Chakraborty, P., Sasi, S., Nair, A.A., Anjum, N., Tripathi, Y.C., 2017: Medicinal applications, phytochemistry and pharmacology of Hymenodictyon excelsum (Roxb.) Wall: A Review. Org. Med. Chem. Int. J., 2, 3, OMCIJ.MS.ID.555589. DOI:10.19080/OMCIJ.2017.02.555589.

8. Chandur, U., Rao, B.G., M.T., Killari, K., 2013: Evaluation of the anti-inflammatory activity of the leaves of $H y$ menodictyon excelsum Wall. Biochem. Pharmacol., 2, 4. DOI: 10.4172/2167-0501.S1.002.

9. Coles, G. C., Bauer, C., Borgsteede, F.H., Geerts, S., Klei, T. R., Taylor, M. A., Waller, P. J., 1992: World Association for Advancement of Veterinary Parasitology (WAAVP) methods for detection of anthelmintic resistance in nematodes of veterinary importance. Vet. Parasitol., 44, 1-2, 35-44. DOI: 10.1016/0304-4017(92)90141-U.

10. Dey, A. R., Akther, S., Hossain, S., Dey, T.R., Bergum, N., 2015: In vitro anthelmintic effect of some medicinal plants against Heamonchus contortus. J. Anim. Sci., 5, 1, 1162-1170. DOI: $10.5455 /$ jasa.20141230103624.

11. Eguale, T., Tadesse, D., Giday, M., 2011: In vitro anthelmintic activity of crude extracts of five medicinal plants against egg-hatching and larval development of Haemonchus contortus. J. Ethnopharmacol., 137, 1, 108-113. DOI: 10.1016/j. jep. 2011.04.063.

12. Flora of West Tropical Africa (FWTA), 1920: Hymenodictyon pachyantha K. Krause [family RUBIACEAE], Engl. Bot. Jahrb., 2, 57, 26.

13. Gatachew, S., Ibrahim, N. I., Abebe, B., Eguale T., 2012: In vitro evaluation of anthelmintic activities of crude extracts of selected medicinal plants against Haemonchus contortus in Alemgena weneda, Ethiopia. Acta Parasitologica Globalis, 3, 2, 20-27. DOI: 10.5829/idosi.apg.2012.3.2.64177.

14. Githiori, J.B., Athanasiadou, S., Thamsborg, S. M., 2006: Use of plants in novel approaches for control of gastrointestinal helminths in livestock with emphasis on small ruminants. Vet. Parasitol., 139, 4, 308-320. DOI: 10.1016/j.vetpar. 2006.04.021.

15. Jabbar, A., Zaman, M.A., Iqbal, Z., Yaseen, M., Shamim, A., 2007: Anthelmintic activity of Chenopodium album (L.) and Caesalpinia crista (L.) against trichostrongylid nematodes of sheep. J. Ethnopharm., 114, 1, 86-91. DOI: 10.1016/j. jep.2007.07.027.

16. Jegede, O. C., Rabiu, B. M., Obeta, S. S., Malang, S. K., Ejiofor, C. E., 2013: Gastrointestinal parasites of ruminants slaughtered in Gwagwalada abattoir, Federal Capital Territory, Abuja, Nigeria. Nig. J. Parasitol., 34, 1, 55-59. DOI:10.5455/ajvs.177135. 
17. Kaplan, R.M., Vidyashankar, A.N., 2012: An inconvenient truth: Global warming and anthelmintic resistance. Vet. Parasitol., 186, 1-2, 70-78. DOI: 10.1016/j.vetpar.2011.11.048.

18. Katiki, L.M., Chagas, A.S., Bizzo, H.R., Ferreira, J.S., Amarante, F. T., 2011: Anthelmintic activity of Cymbopogon martinii, Cymbopogons choenanthus and Mentha piperita essential oils evaluated in four different in vitro tests. Vet. Parasitol., 183, 1-2), 103-108. OI: 10.1016/j.vetpar.2011.07.001.

19. Knox, M.R., Besier, R.B., Le Jambre, L.F., Kaplan, R.M., Torres-Acosta, J. F. J., Miller, J., Sutherland, I., 2012: Novel approaches for the control of helminth parasites of livestock VI: Summary of discussions and conclusions. Vet. Parasitol., 186, 1-2, 143-149. DOI: 10.1016/j.vetpar.2011.11.054.

20. Maitreya, B. B., 2015: An overview of ethnomedicinal plants of family Rubiaceae from Sabarmati river of Gujarat state, Indian. Int. J. Pharma. L. Sci., 6, 5, 4476-4480.

21. Martin, R. J., 1997: Mode of action of anthelmintic drugs. Vet. J., 154, 1, 11-34. DOI: 10.1016/S1090-0233(05)80005.

22. Mc Allister, T. A., Annett, C.B., Cockwell, C.L., Olson, M.E., Wang, Y., Cheeke, P.R., 2001: Studies on the use of Yucca schidigera to control giardiasis. Vet. Parasitol., 97, 2, 85-99. DOI: 10.1016/S0304-4017(01)00394-6.

23. Mitaine-Offer, A.C., Tapondjou, L.A., Djoukeng, J.D., Bouda, H., Lacaille-Dubois, M. A., 2003: Glycoside derivatives of scopoletin and $\mathrm{B}$-sitosterol from Hymenodictyon floribundum. Biochem. Syst. Ecol., 31, 227-228. DOI: 10.1016/ S0305-1978(02)00086-8.

24. Nwosu, C. O., Madu, P. P., Richards, W.S., 2007: Prevalence and seasonal changes in the population of gastrointestinal nematodes of small ruminants in the semi-arid zone of northeastern Nigeria. Vet. Parasitol., 144, 1-2, 118-124. DOI: 10.1016/j.vetpar.2006.09.004.

25. Okoli, B. J., Ayo, R. G., Habila, J.D., Japhet, S. L., Ndukwe, G.I., 2015: In vitro anthelmintic activity of Mucuna pruriens (DC) and Canarium schweinfurthii (Engl) on Ascaris suum. Open. Access. Lib. J., 2, 1-8. DOI:10.4236/oalib.1101102.

26. Oliveira, L. M. B., Bevilaqua, C. M. L., Costa, C. T. C., Macedo, I.T.F., Barros, R.S., Rodrigues, A.C.M., et al., 2009: Anthelmintic activity of Cocos nucifera L. against sheep gastrointestinal nematodes. Vet. Parasitol., 159, 55-59. DOI: 10.1016/j.vetpar.2008.10.018.
27. Payne, V. K., Kollins, E. N., Wabo, P. J., Yondo, J., Komtangi, M., Mpoame, M., Bilong, B.C. F., 2013: In vitro comparative effect of extracts of the seeds of Embelia rowlandii (Myrsinaceae) on the eggs and L1 and L2 larval stages of the parasitic nematode Heligmosomoides bakeri (Nematoda; Heligmosomatidae). Afr. J. Biotech., 12, 2, 205-211. DOI: 10.5897/AJB12. 2297.

28. Pessoa, L.M., Morais, S.M., Bevilaqua, C.M.L., Luciano, J.H.S., 2002: Anthelmintic activity of essential oil of ocimumgratissimum Linn. and eugenol against Haemonchus contortus. Vet. Parasitol., 109, 1-2, 59-63. DOI: 10.1016/ S0304-4017(02)00253-4.

29. Razafimandimbison, S., Bremer, B., 2006: Taxonomic revision of the tribe Hymenodictyeae (Rubiaceae, Cinchonoideae). Bot. J. Linn. Soc., 152, 3, 331-386. DOI: 10.1111/j.1095-8339. 2006.00567.

30. Simon, M.K., Ajanusi, O. J., Abubakar, M.S., Idris, A.L., Suleiman, M.M., 2012: The anthelmintic effect of aqueous methanol extract of Combretum molle (R.Br.x.G.Don) (Combretaceae) in lambs experimentally infected with Haemonchus contortus. Vet. Parasitol., 187, 1-2, 280-284. DOI: 10.1016/j.vetpar.2011.12.022.

31. Simon, M. K., Jegede, O. C., Nafarnda, W. D., 2012: Seasonal influence on Haemonchus contortus infection and response to treatment with albendazole in Yankasa lambs. Adv. Appl. Sci. Res., 3, 4, 2243-2246. DOI:10.5402/2012/515689.

32. Sultana, N., Islam, M. T., Barros de Alencar, M. V. O., Silva, S. W.C., Chowdhury, M.U., Carvalho Melo-Cavalcante, A.A., Mendes de Freitas, R., 2015: Phyto-pharmacological screenings of two Rubiaceae family plants. Afr. J. Pharm. Phamacol., 9, 31, 775-782. DOI: 10.5897/AJPP2015.

33. Taylor, M. A., Coop, R. L., Wall, R. L., 2007: Veterinary Parasitology, 3rd edn., Blackwell Publishing Ltd., Oxford, UK, $872 \mathrm{pp}$.

34. Wabo, P.J., Yondo, J., Fossi, T.O., Marie, C. K., Bilong, B.C. F., Mpoame, M., 2011: The in vitro effects of Chenopodium ambrosioides (Chenopodiaceae) extracts on the parasitic nematode Heligmosomoides bakeri (Nematoda, Heligmosomatidae). J. Pharmacognosy. Phytother., 3, 4, 56-62. DOI: 10. 5897/JPP.

Received March 30, 2019

Accepted June 7, 2019 